\title{
Effect of Sweeteners on Root Dentine Demineralization Using a Microcosm Biofilm Model
}

\author{
Efecto de los Edulcorantes en la Desmineralización de la Dentina \\ Radicular Utilizando un Modelo de Biofilm Microcosmo
}

\author{
Aila Maria Cipriano Leal'; Fabiana Gouveia Rolim; Marta Almeida Silva'; \\ Josie Haydeé Lima Ferreira ${ }^{2} \&$ Glauber Campos Vale ${ }^{1}$
}

LEAL, A. M. C.; ROLIM, F. G.; SILVA, M. A.; FERREIRA, J. H. L. \& VALE, G. C. Effect of sweeteners on root dentine demineralization using a microcosm biofilm model. Int. J. Odontostomat., 13(1):93-96, 2019.

ABSTRACT: The aim of the present study was to evaluate the effect of commercial sweeteners on root dentin demineralization using a microcosm biofilm model. Bovine dentin specimens with pre-determined surface hardness were randomized into six groups according to the studied sweeteners: sucralose, stevia, saccharin, aspartame. Sucrose was used as a positive control and an untreated group as a negative control. The specimens were submitted to biofilm development from one saliva donor and the cariogenic challenge occurred on subsequent five days, twice a day. At the end, the percentage of surface hardness loss (\%SHL) and biomass was determined and submitted to ANOVA followed by Tukey's test. Sucrose presented the highest rate of demineralization, however, all sweeteners tested lead to a statistically higher root demineralization compared to the negative control $(p<0.05)$. Sucrose caused greater demineralization in root dentin, however, the sweeteners were also able to induce it under this biofilm model.

KEY WORDS: sucrose, sweeteners, root dentin.

\section{INTRODUCTION}

Sucrose is considered the most cariogenic diet carbohydrate because it provides a substrate for acid production and generates the energy necessary for extra and intracellular polysaccharides synthesis (Paes Leme et al., 2006; Ccahuana-Vásquez et al., 2007). In addition, it increases the biofilm acidogenicity (Scheie et al., 1984), since it selectively promotes the growth of acidic species (Vale et al., 2007), and reduces the concentrations of $\mathrm{Ca}$ and $\mathrm{Pi}$, critical ions in the de-remineralization process (Paes Leme et al.).

Several sucrose substitutes with low or no cariogenic potential are currently available and are found as ingredients of various candies, chewing gum and beverages. Generally assumed as cariessafe, sweetening beverages with sugar substitutes is becoming increasingly popular. However, research on the effect of commercial sweeteners on the development of caries is considered inconclusive, so far (Matsukubo \& Takazoe, 2006).
It is a challenge to mimic biofilm in vitro due to its complex and populous community of oral bacteria (Filoche et al., 2007). Different biofilm models display a practical and ethical way of exploring new opportunities to investigate the development of dental caries (Salli \& Ouwehand, 2015), including the microcosm (Shu et al., 2000; Filoche et al.; Azevedo et al., 2011; Yang et al., 2011). This model is a laboratory system derived from natural ecosystems, where over 700 species of bacteria coexist. Its objective is to simulate the prevailing conditions of the oral environment in a study environment (Aas et al., 2005).

Therefore, considering the limited evidence on the effect of sweeteners on the development of root caries, the aim of the present study was to evaluate the cariogenic potential of commercial sweeteners in root dentin with polymicrobial biofilm model.

\footnotetext{
${ }^{1}$ Restorative Dentistry Department, Federal University of Piauí, Teresina, Brazil.

${ }^{2}$ Microbiology and Parasitology Department, Federal University of Piauí, Teresina, Brazil.
} 


\section{MATERIAL AND METHOD}

Ethics Considerations: This study was carried out according to the rules of Resolution No. 466/2012 of the Brazil National Health Council, which regulates research in humans and Declaration of Helsinki. The Ethics Committee of the Federal University of Piaui. approved this study under opinion 817177 . The volunteers who donated saliva signed an Informed Consent Form (ICF).

Preparation of Dentine Specimens: The root dentine specimens preparation is described elsewhere (Hara et al., 2003). Briefly, dentin blocks were obtained from bovine incisors previously sterilized in $10 \%$ formaldehyde solution for at least 10 days. Using two diamond discs separated by a $4 \mathrm{~mm}$ spacer, a slice of the cervical third of the root was cut. The slices were sectioned in the mesio-distal direction and the dentin specimens were obtained from the vestibular face. Afterwards, the blocks were flattened and polished, presenting in the end approximate dimensions of $4 \times 4$ $x 2 \mathrm{~mm}$. Initial hardness of the blocks was determined using 5 indentations, spaced $100 \mathrm{~mm}$ apart, using microdurometer with Vickers indenter $(10 \mathrm{~g}$ for 5 seconds).

Experimental Protocol: For the initial inoculum preparation, approximately $10 \mathrm{~mL}$ of stimulated saliva was collected from a donor that refrain oral hygiene for 24 hours. Saliva was inoculated into $100 \mathrm{~mL}$ of semidefined Brain Heart Infusion (BHI) culture medium containing $1 \%$ glucose. After $18 \mathrm{~h}$ in a $10 \% \mathrm{CO}_{2}$ incubator at $37^{\circ} \mathrm{C}$, the suspension was homogenized and $2 \mathrm{~mL}$ were placed in each well of a 24 -well plate containing one dentin specimen each. The 24-well plate was maintained in a $10 \% \mathrm{CO}^{2}$ incubator at $37^{\circ} \mathrm{C}$ for 6 hours for bacterial adhesion in the specimens. After this period, they were transferred to a new 24-well plate containing fresh medium. The following treatments were done for five consecutive days, twice a day: Sucrose $8 \%$ (positive control), Sucralose $8 \%$, Stevia $8 \%$, Saccharin $8 \%$, Aspartame $8 \%$, no treatment (only the medium, negative control). All sweeteners were presented as powder. The concentration used corresponded to 2 teaspoons of sugar $(8 \mathrm{~g})$ in $100 \mathrm{ml}$ of distilled water, considered as a common amount used to sweeten beverages.

Outcomes: At the end of the experiment, the biofilm formed on the specimens was collected and transferred to pre-weighted tubes to determine the biomass and on the root dentine specimens, surface hardness was measured again and described as the percentage of surface hardness loss (\% SHL), using the formula: (Initial Hardness - Post-treatment hardness) x 100/Initial hardness. The SHL was used as an indicator of root dentin demineralization.

Statistical Analysis. The assumptions of equality of variances and normal distribution of errors were checked for all the response variables which complied with the assumptions. SAS software (version 9.0, SAS Institute Inc., Cary, NC, USA) was used for statistical analysis. ANOVA followed by Tukey test were used to compare the variables with the significance level set in $5 \%$.

\section{RESULTS}

Figure 1 shows the root dentin demineralization according to treatments and it is observed that all tested sweeteners showed lower \%SHL $(p<0.05)$ as compared with the caries-positive control (sucrose). However, sucralose induced greater demineralization than the other sweeteners $(p<0.05)$, which do not differ among each other. They all induced higher demineralization compared to the negative control.

Regarding biomass (Fig. 2), only sucrose treated samples showed significantly higher biomass than the others experimental groups $(p<0.05)$, with a similar trend of hardness results.

\section{DISCUSSION}

The results of higher demineralization provoked by sucrose (Fig. 1) was supported by previous reports and is justified by the $\mathrm{pH}$ reduction of biofilm, due to increased acidogenicity (Paes Leme et al.; CcahuanaVásquez et al.). In addition, sucrose hydrolysis releases large amounts of energy that can be used for the extracellular polysaccharides (EPS) synthesis by microorganisms of biofilm and could be the reason of the highest biomass formed under this treatment (Aires et al., 2006; Ccahuana-Vásquez et al.; Vale et al.). Indeed, the tested sweeteners formed less biomass compared to sucrose probably because of the lower EPS production (Fig. 2).

Artificial sweeteners are emerging as a way to replace the consumption of sucrose not only because 


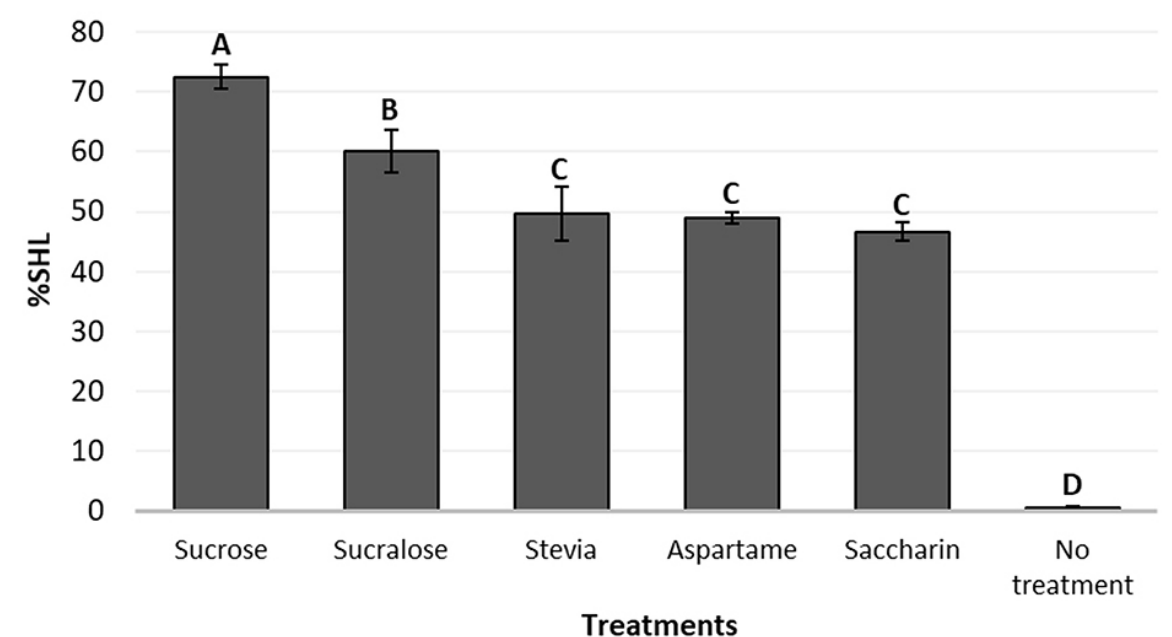

Fig. 1. Mean of root dentin surface hardness loss (\%SHL) according to the treatments. Vertical bars denote standard deviations $(n=4)$. Different letters represent significant differences among treatments $(p<0.05)$.

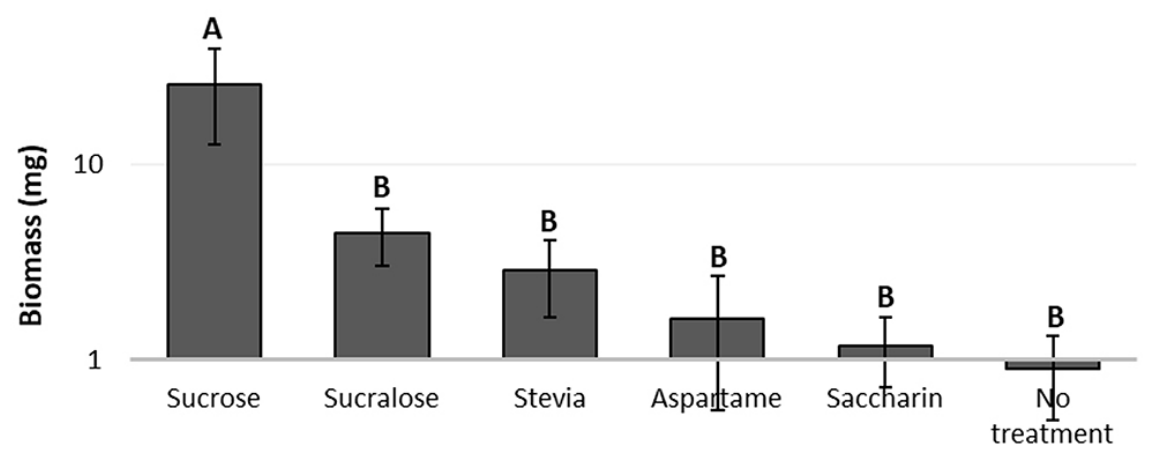

Treatments

0

Fig. 2. Mean of biomass (mg) according to the treatments. Vertical bars denote standard deviations $(n=4)$. Different letters represent significant differences among treatments $(p<0.05)$. The $Y$ axis is shown in logarithm scale for better visualization.

of dental caries but also other health problems like obesity and overweight ( $\mathrm{Ng}$ et al., 2014). Although some studies have suggested that sweeteners are not cariogenic or even have an anticariogenic potential (Das et al., 1992, 1997; Matsukubo \& Takazoe), the results of the present study are in disagreement with those reports, since all tested sweeteners were able to increase root dentine demineralization (Fig. 1), however this discrepancy may be because of the biofilm model (microcosm) and the substrate (root dentine) adopted in this study. On the other hand, the study of Giacaman et al. (2013) using the same sweeteners presented similar results regarding enamel demineralization and according to the authors could be explained because the artificial sweeteners may contain other potentially fermentable carbohydrates, including lactose.

Although a biofilm model that closely mimics the oral environment has been used in this study, it is important to emphasize that these results must be viewed carefully concerning the in vitro design, and should be taken as an initial recording of the subject that should be confirmed by in vivo studies. In conclusion, these results suggest that artificial sweeteners have lower cariogenic potential than sucrose but still capable to induce root dentine demineralization. Therefore, their use is not as cariessafe as commonly assumed, and they should be recommended with caution. 
LEAL, A. M. C.; ROLIM, F. G.; SILVA, M. A.; FERREIRA, J. H. L. \& VALE, G. C. Efecto de los edulcorantes en la desmineralización de la dentina radicular utilizando un modelo de biofilme microcosmo. Int. J. Odontostomat., 13(1):93-96, 2019.

RESUMEN: El objetivo del presente estudio fue evaluar el efecto de los edulcorantes comerciales en la desmineralización de la dentina radicular utilizando un modelo de biofilm microcosmo. Se asignaron al azar muestras de dentina bovina con una dureza de la superficie predeterminada de acuerdo con los edulcorantes estudiados: sucralosa, estevia, sacarina, aspartame. La sacarosa se utilizó como control positivo y un grupo no tratado como control negativo. Las muestras se enviaron al desarrollo de biopelículas de un donante de saliva y el desafío cariogénico se produjo en los siguientes cinco días, dos veces al día. Al final, se determinó el porcentaje de pérdida de dureza de la superficie (\% PDS) y biomasa y se aplicó un estudio estadístico de ANOVA seguido de la prueba de Tukey. La sacarosa presentó la mayor tasa de desmineralización; sin embargo, todos los endulzantes probados condujeron a una desmineralización de la raíz estadísticamente mayor en comparación con el control negativo $(p<0,05)$. La sacarosa causó una mayor desmineralización en la dentina de raíz, sin embargo, los edulcorantes también fueron capaces de inducirla bajo este modelo de biofilm.

PALABRAS CLAVE: sacarosa, edulcorantes, dentina radicular.

\section{REFERENCES}

Aas, J. A.; Paster, B. J.; Stokes, L. N.; Olsen, I. \& Dewhirst, F. E. Defining the normal bacterial flora of the oral cavity. J. Clin. Microbiol., 43(11):5721-32, 2005.

Aires, C. P.; Tabchoury, C. P.; Del Bel Cury, A. A.; Koo, H. \& Cury, J. A. Effect of sucrose concentration on dental biofilm formed in situ and on enamel demineralization. Caries Res., 40(1):28-32, 2006.

Azevedo, M. S.; van de Sande, F. H.; Romano, A. R. \& Cenci, M. S. Microcosm biofilms originating from children with different caries experience have similar cariogenicity under successive sucrose challenges. Caries Res., 45(6):510-7, 2011.

Ccahuana-Vásquez, R. A.; Tabchoury, C. P.; Tenuta, L. M.; Del Bel Cury, A. A.; Vale, G. C. \& Cury, J. A. Effect of frequency of sucrose exposure on dental biofilm composition and enamel demineralization in the presence of fluoride. Caries Res., 41(1):9-15, 2007.

Das, S.; Das, A. K.; Murphy, R. A. \& Warty, S. Cariostatic effect of aspartame in rats. Caries Res., 31(1):78-83, 1997.

Das, S.; Das, A. K.; Murphy, R. A.; Punwani, I. C.; Nasution, M. P. \& Kinghorn, A. D. Evaluation of the cariogenic potential of the intense natural sweeteners stevioside and rebaudioside A. Caries Res., 26(5):363-6, 1992.

Filoche, S. K.; Soma, K. J. \& Sissons, C. H. Caries-related plaque microcosm biofilms developed in microplates. Oral Microbiol. Immunol., 22(2):73-9, 2007.
Giacaman, R. A.; Campos, P.; Muñoz-Sandoval, C. \& Castro, R. J. Cariogenic potential of commercial sweeteners in an experimental biofilm caries model on enamel. Arch. Oral Biol., 58(9):1116-22, 2013.

Hara, A. T.; Queiroz, C. S.; Paes Leme, A. F.; Serra, M. C. \& Cury, J. A. Caries progression and inhibition in human and bovine root dentine in situ. Caries Res., 37(5):339-44, 2003.

Matsukubo, T. \& Takazoe, I. Sucrose substitutes and their role in caries prevention. Int. Dent. J., 56(3):119-30, 2006.

Ng, M.; Fleming, T.; Robinson, M.; Thomson, B.; Graetz, N.; Margono, C.; Mullany, E. C.; Biryukov, S.; Abbafati, C.; Abera, S. F. et al. Global, regional, and national prevalence of overweight and obesity in children and adults during 19802013: a systematic analysis for the Global Burden of Disease Study 2013. Lancet, 384(9945):766-81, 2014.

Paes Leme, A. F.; Koo, H.; Bellato, C. M.; Bedi, G. \& Cury, J. A. The role of sucrose in cariogenic dental biofilm formation-new insight. J. Dent. Res., 85(10):878-87, 2006.

Salli, K. M. \& Ouwehand, A. C. The use of in vitro model systems to study dental biofilms associated with caries: a short review. J. Oral Microbiol., 7:26149, 2015.

Scheie, A. A.; Arneberg, P.; Orstavik, D. \& Afseth, J. Microbial composition, $\mathrm{pH}$-depressing capacity and acidogenicity of 3 -week smooth surface plaque developed on sucroseregulated diets in man. Caries Res., 18(1):74-86, 1984.

Shu, M.; Wong, L.; Miller, J. H. \& Sissons, C. H. Development of multi-species consortia biofilms of oral bacteria as an enamel and root caries model system. Arch. Oral Biol., 45(1):27-40, 2000

Vale, G. C.; Tabchoury, C. P.; Arthur, R. A.; Del Bel Cury, A. A.; Paes Leme, A. F. Cury, J. A. Temporal relationship between sucrose-associated changes in dental biofilm composition and enamel demineralization. Caries Res., 41(5):406-12, 2007.

Yang, L.; Liu, Y.; Wu, H.; Hóiby, N.; Molin, S. \& Song, Z. J. Current understanding of multi-species biofilms. Int. J. Oral Sci., 3(2):74-81, 2011.

Corresponding author:

Prof. Dr. Glauber Campos Vale

Restorative Dentistry Department

Federal University of Piauí

Campus Universitário Ministro Petrônio Portella -

Bairro Ininga

CEP: 64049-550 Teresina

BRAZIL

Email: glauber@ufpi.edu.br

Received: 09-10-2018

Accepted: 07-12-2018 